\title{
UPAYA GURU PPKN DALAM MENCEGAH TAWURAN PELAJAR DI SMK BINA KARYA 1 KABUPATEN KARAWANG
}

\author{
${ }^{1}$ Muhamad Jawir Ripa'i \\ ${ }^{2}$ Yogi Nugraha \\ ${ }^{3}$ Aris Riswandi Sanusi \\ Universitas Buana Perjuangan Karawang \\ 1pk15.muhamadripai@mhs.ubpkarawang.ac.id \\ 2yogi.nugraha@ubpkarawang.ac.id \\ 33arissanusi@ubpkarawang.ac.id
}

\begin{abstract}
This study aims to determine the efforts made by the PPKn teacher in preventing and overcoming brawls between schools at SMK Bina Karya 1, Karawang Regency. This research uses a qualitative approach with descriptive methods. The subject of this research is the Pancasila and Citizenship Education teacher at SMK Bina Karya I Karawang. Data collection techniques using interviews, observation, and documentation studies. Data analysis techniques with the results of interviews, observation and documentation with triangulation. The results showed that the efforts made by PPKn teachers to prevent the occurrence of brawls at SMK Bina Karya I Karawang was to instill Pancasila values, especially the first precepts, namely divinity. By making the dhuha prayer program in congregation regularly on Tuesday and Wednesday. This was done as an effort to get students closer to God while providing character education to students.
\end{abstract}

Keywords: Student Brawl, PPKn teacher efforts

\begin{abstract}
ABSTRAK
Penelitian ini bertujuan mengetahui upaya yang dilakukan oleh pihak Guru PPKn dalam mencegah dan menanggulangi tawuran antara sekolah di SMK Bina Karya 1 Kabupaten Karawang. Penelitian ini menggunakan pendekatan kualitatif dengan metode deskriptif. Subjek penelitian ini adalah guru Pendidikan Pancasila dan Kewarganegaraan di SMK Bina Karya I Karawang. Tenknik pengumpulan data menggunakan wawancara, observasi, dan studi dokumentasi Teknik analisis data dengan hasil wawancara, observasi dan dokumentasi dengan triangulasi. Hasil penelitian menunjukan bahwa Upaya yang dilakukan oleh guru PPKn untuk mencegah terjadinya tawuran di SMK Bina Karya I Karawang adalah menanamkan nilai-nilai pancasila terutama sila pertama yaitu ketuhanan. Dengan membuat program shalat dhuha berjamaah secara rutin di hari selasa dan rabu. Hal tersebut dilakukan sebagai upaya mendekatkan pelajar dengan tuhan sekaligus memberikan pendidikan karakter kepada pelajar.
\end{abstract}

Kata Kunci : Tawuran Pelajar, Upaya guru PPKn 


\section{PENDAHULUAN}

Semakin tingginya konflik yang terjadi di Indonesia maka masyarakat semakin rentan mengalami perpecahan antar kelompok baik kelompok besar ataupun kelompok kecil. Sama halnya dengan d Indonesia banyak terjadi konflik dalam dunia pendidikan daintaranya adalah kenakalan remaja seperti tawuran antarpelajar yang memberikan dampak negatif bagi siswa. Kenakalan yang terjadi pada remaja menyebabkan remaja melakukan perilaku menyimpang atau perilaku negatif yang seringkali menyebabkan siswa terkait hukum pidana (Setyawan, 2014:2).

Perilaku menyimpang yang banyak terjadi dikalangan remaja adalah perkelahian pelajar atau yang sering disebut dengan tawuran antar pelajar. Tawuran antar pelajar saat ini telah menjadi hal yang tidak tabu sedangkan seharusnya pelajar menghindari perilaku-perilaku menyimpang seperti tawuran. Begitupun dengan keadaan orang tua yang semakin resah melihat fenomena tawuran yang banyak terjadi di kalangan pelajar sehingga menyebabkan orang tua semakin merasa khawatir (Setyawan, 2014:4). Dengan demikian tawuran sudah seharusnya dihindari oleh kalangan-kalangan terpelajar karena hal tersebut adalah perilaku menyimpang yang meresahkan masyarakat terutama orang tua dari anak-anaknya yang merupakan para pelajar.

Konflik-konflik tawuran semakin banyak terdengar di telinga masyarakat karena masyarakat mengetahui dan melihat bahwa tawuran terjadi anatara dua kelompok yang saling menyerang. Istilah tawuran bukanlah istilah yang asing bagi masyarakat indonesia karena fenomena tawuran banyak terjadi di Indonesia. Tawuran merupakan perilaku menyerang antar kelompok dengan melakukan tindakan kekerasan dimana hal tersebut telah melanggar nilai sila yang ketiga yaitu persatuan Indonesia sedangkan menjunjung tinggi persatuan merupakan kewajiban warga negara Indonesia (Dianlestari, 2015:2).

Kasus-kasus tawuran yang terjadi di Indonesia sudah banyak terjadi diantaranya adalah data Komnas Perlindungan Anak (PA) yang mencatat terjadi 339 kasus tawuran pada tahun 2011, 128 kasus tawuran pda tahun 2012 dan 229 kasus antar pelajar pada tahun 2013 (Setyawan, 2014:6). Selain itu pada tahun 2013 terjadi 255 kasus tawuran antarpelajar SMP dan SMA yang terjadi di Jakarta yang dinyatakan mengalami peningkatan sebesar $44 \%$ dari tahun sebelumnya yang hanya terjadi 128 kasus (Aprilia, 2014). Dengan demikian dapat disimpulkan bahwa kasuskasus tawuran semakin tahun semakin meningkat di Indonesia, sehingga hal tersebut menjadi fenomena yang perlu diperhatikan.

Usia para pelajar merupakan usia yang tergolong kedalam masa remaja. Masa remaja awal memiliki rentang usia duabelas sampai limabelas tahun, usia remaja pertengahan memiliki rentang usia lima belas sampai delapan belas tahun dan usia remaja akhir dengan rentang usia delapan belas sampai dua puluh satu tahun (Aprilia \& Indrijati, 2014:3). Adapun siswa SMK di Indonesia pada umumnya berada pada masa remaja pertengahan yaitu lima belas sampai delapan belas tahun.

\section{METODE}


Penelitian ini menggunakan pendekatan kualitatif, dengan itu hasil penelitian ini bersifat analisis-deskriptif yaitu berupa kata-kata tertulis atau lisan dari perilaku yang diamati terutama terkait dengan bagaimana upaya yang dilakukan oleh pihak Guru PPKn dalam mencegah dan menanggulangi tawuran antara sekolah di SMK Bina Karya 1 Kabupaten Karawang.

Subjek penelitian ini adalah guru Pendidikan Pancasila dan Kewarganegaraan di SMK Bina Karya I Karawang. Objek penelitian peneliti yaitu mengenai upaya yang dilakukan oleh pihak Guru PPKn dalam mencegah dan menanggulangi tawuran antara sekolah di SMK Bina Karya 1 Kabupaten Karawang.

Teknik pengumpulan data merupakan cara yang digunakan peneliti untuk mendapatkan data dalam suatu penelitian. Teknik pada penelitian ini terdiri dari ; wawancara, observasi, dan studi dokumentasi Teknik analisis data dengan hasil wawancara, observasi dan dokumentasi dengan triangulasi. Analisis data dalam penelitian kualitatif dilakukan sejak sebelum memasuki lapangan, selama di lapangan dan setelah selesai di lapangan, lalu melakukan reduction (reduksi data), display (penyajian data), dan Conclusion drawing/verification.

\section{HASIL DAN PEMBAHASAN}

Sebagai upaya pencegahan terjadinya tawuran guru PPKn berfokus pada pendidikan karakter pelajar, mencari solusi dengan menamkan nilai-nilai yang mampu memperbaiki moralitas siswa. Adapun yang dilakukan oleh guru PPKn bekerjasama dengan guru agama dan pihak sekolah yaitu mengadakan shalat dhuha berjama'ah sebagai upaya menanamkan nilai-nilai ketuhanan di sila pertama kepada siswa. Guru PPKn meyakini dengan adanya program shalat dhuha berjamah yang dilakukan rutin di hari selasa dan rabu mampu memperbaiki sikap dan etika pelajar. Guru berharap kesadaran dan rasa mawas diri pelajar semakin meningkat dengan adanya program-program keagamaan.

Hal tersebut sejalan dengan pandangan Kartini Kartono menyebutkan bahwa untuk mencegah tawuran antar pelajar atau kenakalan remaja pada umumnya adalah:

“a) Banyak mawas diri, melihat kelemahan dan kekurangan sendiri, dan melakukan koreksi terhadap kekeliruan yang sifatnya tidak mendidik dan tidak menuntun; b) Memberi kesempatan kepada remaja untuk beremansipasi dengan cara yang baik dan sehat; c) Memberikan bentuk kegiatan dan pendidikan yang relevan dengan kebutuhan remaja zaman sekarang serta kaitannya dengan pengembangan bakat dan potensi remaja" (Kartini Kartono, 2016: 30).

Dengan demikian guru PPKn berusaha memberikan kesempatan kepada pelajar untuk melakukan kegiatan dan pendidikan yang baik sehingga mampu mmeberikan peluang untuk mengembangkan potensi dan karakter yang baik.

\section{SIMPULAN (PENUTUP)}

Pada saat pembelajaran berlangsung, guru PPKn selalu tegas dalam menekankan kedisiplinan pelajar didalam kelas terutama pada saat berdoa. Hal itu dilakukan agar pelajar menyadari betapa pentingnya nilainilai kedisiplinan dalam kehidupan. Guru berusaha menyampaikan materi pelajaran dengan jelas dan dapat dipahami makna- 
makna yang terkandung dalam setiap materi ajar yang disampaikan. Selain itu, guru selalu memberikan penjelasan mengenai implementasi dari materi yang diajarkan mengenai pendidikan pancasila dan kewarganegaraan. Karena materi ajar PPKn tidak terlepas dari pendidikan karakter maka guru selalu berusaha menyisipkan ceramah mengenai bahaya dan dampak tawuran. Hal tersebut dilakukan agar pelajar memahami bahwa tawuran merupakan tindakan tidak terpuji yang harus dihindari.

Guru PPKn juga menyatakan bahwa pencegahan terhadap tawuran bukanlah hal yang mudah karena tawuran di SMK Bina Karya I Karawang merupakan masalah yang sudah turun-temurun dari sejak awal berdirinya sekolah. Oleh karena itu dalam pencegahan tentu bukan hanya dilakukan oleh upaya guru PPKn di dalam ataupun diluar kelas akan tetapi perlu dorongan dari berbagai pihak seperti orang tua, pemerintah daerah, kepolisian dan lingkungan sekitar. Pencegahan akan menjadi lebih mudah dengan adanya kerjasama yang baik antar pihak-pihak yang memiliki otoritas dan wewenang. Contohnya adalah seperti membubarkan kerumunan-kerumunan pelajar di setiap jalan karena tawuran selalu berawal dari adanya kerumunan yang berkumpul dan merencanakan untuk saling menyerang. Jika pengawasan lingkungan sering dilakukan maka kasus-kasus tawuran akan semakin berkurang. Selain itu upaya yang dilakukan oleh guru PPKn sebagai bentuk pencegahan adalah dengan memberikan pesan-pesan moral yang disampaikan pada saat pembelajaran berlangsung. Memberikan nasehat-nasehat kepada siswa-siswi mengenai bahaya dari kenakalan-kenakalan yang dilakukan sepeti tawuran diantaranya adalah berurusan dengan kepolisian, dikeluarkan dari sekolah dan meresahkan masyarakat sehingga bisa saja terjadi hal-hal yang tidak diinginkan sebagai tindakan represif dari masyarakat secara sepihak. Dengan diberikan nasehatnasehat dan pesan-pesan positif diharapkan mampu membantu siswa-siswi untuk memiliki kesadaran beretika dengan baik dan mencegah terjadinya perilaku tawuran antar pelajar.

\section{DAFTAR PUSTAKA}

Aly, Abdullah. 2011. Pendidikan Islam Multikultural di Pesantren. Yogyakarta: Pustaka Pelajar.

Basri, Said. 2013. Fenomena tawuran antar pelajar dan konsekuensinya. Skripsi : Yogyakarta.

Dianlestari, Meidayanti. 2015. Upaya Mengatasi Kenakalan Remaja : Tawuran di SMAN 4 Kabupaten Tangerang. Skripsi Semarang : Universitas Negeri Semarang.

Djamarah, Syaiful B. 2010. Guru dan Anak Didik dalam Interaksi Edukatif: Suatu Pendekatan Teoretis Psikologis. Jakarta: Rineka Cipta.

Hamalik, Oemar. 2009. Pendidikan Guru : Berdasarkan Pendekatan Kompetensi. Jakarta : PT. Bumi Aksara.

Idi, Abdullah. 2016. Pengembangan Kurikulum Teori \& Praktik. Jakarta : PT. Raja Grafindo Persada.

Indrijati, Aprilia. 2014. Jurnal Vol. 3 No.01. Hubungan Antara Kecerdasan Emosi dengan perilaku Tawuran pada Remaja Laki-Laki yang Pernah Terlibat Tawuran di SMK “B” Jakarta. Jurnal Psikologi Pendidikan dan Perkembangan.

Kartono, Kartini. 2004. Patologi Sosial Jildi 1. Jakarta : Rajawali Pers.

Kirom, Askhabul. 2017. Jurnal Pendidikan Agama Islam. Volume 3 Nomor 1. Peran Guru Dan Peserta Didik 
Dalam Proses Pembelajaran Berbasis Multikultural.

Marlina. 2012. Peradilan Pidana Anak di Indonesia. Refika Aitama: Bandung.

Moleong, Lexy J. 2016. Metodologi Penelitian Kualitatif. Bandung : Remaja Rosdakarya.

Nafis, Muhammad M. 2011. Ilmu Pendidikan Islam. Yogyakarta: Teras.

Novarianto, Wahyu. 2018. Upaya Penanggulangan Terjadinya Tawuran Antar Pelajar. Skripsi Bandar Lampung : Universitas Lampung.

Setyawan, Heru. 2014. Kebijakan Sekolah Dalam Mengatasi Tawuran Antar Pelajar di SMA Negeri 2 Ngaglik Sleman. Skripsi Yogyakarta : Universitas Negeri Yogyakarta.

Sagala, Syaiful. 2009. Kemampuan Profesional Guru dan Tenaga Kependidikan. Bandung: Alfabeta.
Sarwono. 2016. Psikologi Remja Edisi Revisi. Jakarta: Rajawali Pers.

Savitri, Sinaga, dkk. 2015. Kajian Kriminologi Terhadap Perilaku Tawuran Antar Pelajar Sekolah Menengah Atas di Kota Yogyakarta. Universitas Gadjah Mada: Yogyakarta.

Simen, Dewi A. 2013. Tinjauan Yuridis Terhadap Tindak Pidana Peekelahian Kelompok Yang Menyebabkan Kematian Oleh Geng Motor. Skripsi Makassar : Universitas Hasauddin.

Sudarsono, 2005. Kenakalan Remaja. Rineka Cipta: Jakarta.

Sugiyono. 2017. Metode penelitian kuantitatif, kualitatif, dan R\&D. Bandung : Alfabeta. 